\title{
DÜBLIN
}

Technological University Dublin

ARROW@TU Dublin

\section{Ozone Inactivation of Acid Stressed Listeria Monocytogenes and Listeria Innocua in Orange Juice Using a Bubble Column}

\author{
Sonal Patil \\ Technological University Dublin, sonalpatil81@gmail.com \\ Vasilis Valdramidis \\ Technological University Dublin \\ Jesus Maria Frias \\ Technological University Dublin, Jesus.Frias@tudublin.ie
}

See next page for additional authors

Follow this and additional works at: https://arrow.tudublin.ie/schfsehart

Part of the Food Microbiology Commons, and the Food Processing Commons

\section{Recommended Citation}

Patil, S., Valdramidis, V.P. , Cullen, P.J. , Frias, J. , Bourke P. (2010): Ozone inactivation of acid stressed

Listeria monocytogenes and Listeria innocua in orange juice using a bubble column. Food Control, 21(13)

1723-1730. doi:10.1016/j.foodcont.2010.04.031

This Article is brought to you for free and open access by the School of Food Science and Environmental Health at ARROW@TU Dublin. It has been accepted for inclusion in Articles by an authorized administrator of ARROW@TU Dublin. For more information, please contact arrow.admin@tudublin.ie, aisling.coyne@tudublin.ie, gerard.connolly@tudublin.ie.

Funder: National Development Plan 2000-2006, through the Food Institutional Research Measure, administered by the Department of Agriculture, Fisheries \& Food, Ireland.

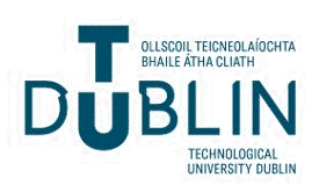




\section{Authors}

Sonal Patil, Vasilis Valdramidis, Jesus Maria Frias, Patrick Cullen, and Paula Bourke

This article is available at ARROW@TU Dublin: https://arrow.tudublin.ie/schfsehart/66 
1 Title: "Ozone inactivation of acid stressed Listeria

2 monocytogenes and Listeria innocua in orange juice using a

\section{3 bubble column"}

4

5 S. Patil, V.P. Valdramidis, P.J. Cullen, J. Frias, and P. Bourke*

6

7 School of Food Science and Environmental Health, Dublin Institute of Technology,

8 Cathal Brugha Street, Dublin 1, Ireland

22 * Corresponding author. Tel: +353-14027594; Fax: +353-14024495; E-mail: paula.bourke@dit.ie 


\section{Abstract}

26 Orange juice inoculated with Listeria monocytogenes strains ATCC 7644, NCTC 11994

27 and Listeria innocua NCTC $11288\left(10^{6} \mathrm{CFU} / \mathrm{ml}\right)$ as challenge microorganisms was

28 treated with direct ozone at $0.098 \mathrm{mg} / \mathrm{min} / \mathrm{ml}$ for different time periods $(0-8 \mathrm{~min})$ using an

29 ozone bubble column. Ozone treatment of mild acid stressed and mild acid stress-

30 habituated $(\mathrm{pH}$ 5.5) cells of $L$. monocytogenes resulted in higher inactivation times

31 compared to control non-acid stressed cells. Additionally acid stressed cells habituated in

32 orange juice (ATCC 7644 \& NCTC 11288), showed higher inactivation times during

33 ozonation by comparison with the control as well as the mild-acid stressed cells. Overall

34 the gaseous ozone treatment applied to orange juice resulted in a population reduction of

$355 \log$ cycles within a time range that varied between 5 to 9 min.

37 Key words: Listeria monocytogenes, ozone, bubble column, non-thermal inactivation,

38 acid stress, orange juice, microbial kinetics

39

40

41

42

43

44

45

46

47 


\section{Introduction}

49 Listeria monocytogenes is a Gram positive, psychrotrophic pathogen ubiquitous in the

50 environment and has been found in fruits and vegetables. L. monocytogenes is capable of

51 growing at refrigeration temperatures in high salt and acid foods. L. innocua is often

52 selected for inactivation studies because it is non pathogenic but still closely related to $L$.

53 monocytogenes (Picart, Dumay \& Cheftel, 2002). No outbreaks involving $L$.

54 monocytogenes in fruit juices have been reported; however this pathogen has been

55 isolated from unpasteurised apple juice $(\mathrm{pH} 3.78)$ and apple-raspberry juice blend ( $\mathrm{pH}$

56 3.75) after 1 day storage at $5^{\circ} \mathrm{C}$ (Sado, Jinneman, Husby, Sorg \& Omiecinsky, 1998).

57 This pathogen is a vehicle of human listeriosis which survived well beyond the normal

58 shelf life of unsterile orange juices (Ryser \& Marth, 1991). Oyarzábal, Nogueira and

59 Gombas (2003) studied the survival of L. monocytogenes and other foodborne pathogens

60 in apple, orange, pineapple, and white grape juice concentrates and showed that these

61 pathogens were recoverable from all concentrates through 12 weeks of storage at $-23{ }^{\circ} \mathrm{C}$.

62 The low $\mathrm{pH}$ of fruit juices plays an important role in survival of food borne pathogens.

63 The ability of L. monocytogenes to respond to low $\mathrm{pH}$ conditions plays an integral role in

64 its survival and resistance to acidic foods (Cotter, Gahan \& Hill, 2000), thus affecting the

65 food processing and preservation protocols. The organism can become highly resistant to

66 even extremely acidic conditions due to stress hardening (Lou \& Yousef, 1997). Some

67 studies have shown that Acid Tolerance Response (ATR) of L. monocytogenes, as a

68 consequence of stress hardening, can result in its increased thermal tolerance in apple,

69 orange and white grape juice (Mazzotta, 2001). Strategies to meet consumer demands for

70 better quality food products include minimal processing, which could introduce potential 
71 for pathogen survival. Caggia, Ombretta, Restuccia and Randazzo (2009) reported that

72 orange juice and minimally processed orange juice slices can support the growth of acid

73 adapted L. monocytogenes. In food processing technologies, there is an extensive use of

74 low $\mathrm{pH}$ environments (decontamination by acetic acid in beef processing, fermentation

75 etc.) which can result in the alteration of the cellular physiology of the pathogen either by

76 de novo protein synthesis or by changes in the fatty acid composition of the cell

77 membrane (Foster 1991, Phan-Thanh, Mahouin, \& Alige, 2000). This can lead to

78 enhanced resistance to any further or subsequent acid stress which may be part of a

79 processing treatment. This acid tolerance is also termed as acid habituation which is the

80 increased resistance to extreme $\mathrm{pH}$ conditions after adaptation to sublethal acidic

81 environments (Koutsoumanis \& Sofos, 2004). L. monocytogenes is more resistant than

82 many foodborne pathogens to organic acids and can be difficult to control in food

83 processing facilities (Johnson, 2003), therefore it is necessary to evaluate responses of

84 Listeria cells exposed to different acidic conditions.

85 The US Food and Drug Administration (US FDA) issued a final rule requiring fruit and 86 vegetable juice producers to apply a 5-log pathogen reduction process (US FDA, 2004a).

87 In recent years consumers have increasingly sought ready to use 'fresh-like' products,

88 which are usually refrigerated. This has led the food industry to develop alternative 89 processing technologies, to produce foods with a minimum of nutritional,

90 physicochemical, or organoleptic changes induced by these technologies (Esteve \&

91 Frigola, 2007), whilst maintaining safety profiles with respect to pathogens of concern.

92 The FDA's approval of ozone as a direct additive to food in 2001 triggered interest in

93 ozone applications, with a number of commercial fruit juice processors in the US and 
94 Europe employing ozone for pasteurization, resulting in industry guidelines being issued

95 by the FDA (USFDA, 2004b). Ozone is a triatomic allotrope of oxygen and is

96 characterized by a high oxidation potential that conveys bactericidal and viricidal

97 properties (Burleson, Murray \& Polard, 1975; Kim, Yousef \& Dave, 1999). Ozone

98 inactivates microorganisms through oxidization and residual ozone decomposes to

99 nontoxic products (i.e. oxygen) making it an environmentally friendly antimicrobial agent

100 for use in the food industry (Kim et al., 1999). Ozone as an oxidant is used in natural

101 water treatment, washing and disinfecting of fruits and vegetables, and juice processing

102 to inactivate pathogenic and spoilage microorganisms (Muthukumarappan, Halaweish \&

103 Naidu, 2000). In a gas or aqueous phase, ozone has been used to inactivate

104 microorganisms and decontaminate meat, poultry, eggs, fish, fruits, vegetables and dry

105 foods (Fan, Song, McRae, Walker \& Sharpe, 2007). Tiwari, Muthukumarappan,

106 O'Donnell and Cullen (2008, 2009a $)$ and Tiwari, O'Donnell, Patras, Brunton and Cullen

$107\left(2009_{\mathrm{b}}\right)$ recently highlighted that nutritional quality depends on the ozone control

108 parameters of concentration and gas flow rate. Achieving rapid microbial inactivation

109 using optimized control parameters while retaining the nutritional quality is of overall

110 importance.

111 The objectives of this study were to investigate (i) the efficacy of gaseous ozone

112 treatment for reduction of $L$. monocytogenes and $L$. innocua at ambient temperature in

113 orange juice, (ii) ozone treatment efficacy in orange juice inoculated with the acid

114 stressed Listeria population, using a range of acid stress conditions, namely mild acid

115 stressed, mild acid stress-habituated and acid stressed but habituated in orange juice.

\section{2. Materials and Methods}




\section{$117 \quad 2.1$ Bacterial strains}

118 Three strains of Listeria were used in this study. L. monocytogenes ATCC 7644, L.

119 monocytogenes NCTC 11994, and L. innocua NCTC 11288 obtained from microbiology

120 stock culture, School of Food Science and Environmental Health, Dublin Institute of

121 Technology. Strains were maintained as frozen stocks at $-70{ }^{\circ} \mathrm{C}$ in the form of protective

122 beads, which were plated onto tryptic soy agar (TSA, Barcelona, Scharlau Chemie) and

123 incubated overnight at $37^{\circ} \mathrm{C}$ to obtain single colonies before storage at $4{ }^{\circ} \mathrm{C}$.

\section{$124 \quad 2.2$ Preparation of orange juice}

125 Oranges (variety: Navalate, Peru) were purchased from a local market and squeezed with

126 a fruit juicer (Rowenta PA4002NEO). The fresh orange juice was then submitted to a

127 finishing process by passing through a sieve (Laboratory test sieve, Retsch, Germany) of

$1281 \mathrm{~mm}$ diameter (mesh no. 18) to reduce the pulp content (Patil, Bourke, Frias, Tiwari \&

129 Cullen, 2009a ). All juice preparations were stored at $4{ }^{\circ} \mathrm{C}$. The $\mathrm{pH}$ was measured using a

$130 \mathrm{pH}$ meter with a glass electrode (Orion Model, England) and was found to be in the range

131 of 3.5-3.7.

\section{$132 \quad 2.3$ Experimental design}

133 In order to investigate the efficacy of ozone against L. monocytogenes and L. innocua

134 microbial populations, four different conditions were investigated;

135 a) To obtain a non acid stressed control Listeria population, cells were grown in TSB

136 without glucose (TSB-G). TSB-G was used as the basic medium for obtaining control

137 cells as presence of glucose in the medium results in mild acid stress of cells by reducing

138 the $\mathrm{pH}$ of TSB to 4.9. 
139 b) To obtain mild acid stressed Listeria population, cells were grown in TSB with glucose $140 \quad(\mathrm{TSB}+\mathrm{G}, 0.25 \%)$.

141 c) To obtain $1 \mathrm{~h}$ mild acid stress-habituated Listeria population, cells were grown in $142 \mathrm{TSB}+\mathrm{G}, 0.25 \%$ and then habituated at $\mathrm{pH} 5.5$ (adjusted using $80 \%$ lactic acid) for $1 \mathrm{~h}$ and

143 to obtain $18 \mathrm{~h}$ mild acid stress-habituated Listeria population, cells were grown in $144 \mathrm{TSB}+\mathrm{G}, 0.25 \%(\mathrm{pH} 5.5)$.

145 d) To obtain a Listeria population habituated in orange juice, cells were grown in $146 \mathrm{TSB}+\mathrm{G}, 1.25 \%$ leading to acid stressed cells which were then habituated in orange juice 147 for $90 \mathrm{~min}$ at $37^{\circ} \mathrm{C}$. Cells prepared under these different conditions were then treated 148 with ozone in orange juice.

\section{$149 \quad 2.4$ Preparation of cell suspensions and culture conditions}

150 For the first (a) and second investigation (b), a single isolated colony of each strain was

151 inoculated separately either in TSB-G or in TSB+G, $0.25 \%$ to produce non acid stressed 152 cells (control sample) and mild acid stressed cells, respectively. Cultures were then 153 incubated overnight at $37^{\circ} \mathrm{C}$ and were then harvested by centrifugation (SIGMA 2K15, 154 Bench Top Refrigerated Ultracentrifuge, AGB scientific LTD.) at 10,000 rpm for 10min 155 at $4{ }^{\circ} \mathrm{C}$. The cell pellet was washed twice with sterile phosphate buffered saline (PBS, 156 Oxoid LTD, UK). The pellet was re-suspended in PBS and the bacterial density was 157 determined by measuring absorbance at 550nm using McFarland standard (BioMérieux, 158 Marcy -l'Etoile, France). The inoculum was then diluted in maximum recovery diluent 159 (MRD, Scharlau Chemie) to obtain approximately $10^{7} \mathrm{cells} / \mathrm{ml}$. For each investigation, the 160 cell concentration was further diluted in orange juice to yield a final concentration of $10^{6}$ 161 cells $/ \mathrm{ml}$ and then ozone treatment was applied. 
162 For the third investigation (c), two acid stress-habituation conditions were imposed, i.e.,

1631 hour and 18 hours. For the 1 hour habituation environment, working cultures were 164 grown overnight in $\mathrm{TSB}+\mathrm{G}, 0.25 \%$ at $37{ }^{\circ} \mathrm{C}$ (thus creating a mild acid stress

165 environment). Cells were then harvested by centrifugation at 10,000 rpm for $10 \mathrm{~min}$ at 4

$166{ }^{\circ} \mathrm{C}$. The cell pellet was washed twice with sterile PBS, re-suspended in $10 \mathrm{ml}$ TSB 167 adjusted to $\mathrm{pH} 5.5$, and incubated at $37{ }^{\circ} \mathrm{C}$ for $1 \mathrm{~h}$ (Cheng, Yu \& Chou, 2003; Caggia et 168 al., 2009). To prepare $18 \mathrm{~h}$ habituated cells, bacterial strains were grown directly in

$169 \mathrm{TSB}+\mathrm{G}, 0.25 \%\left(\mathrm{pH} \mathrm{5.5)}\right.$ at $37{ }^{\circ} \mathrm{C}$. The mild acid stress-habituated cells were diluted in

170 MRD ( $\mathrm{pH} 5.5)$ to yield approximately $10^{7}$ cells $/ \mathrm{ml}$, with further dilution in orange juice

$171(\mathrm{pH} 3.5-3.7)$ to a final concentration of $10^{6}$ cells $/ \mathrm{ml}$ and then ozone treatment was applied.

172 For the fourth investigation (d) the working cultures were incubated overnight in $\mathrm{TSB}+\mathrm{G}$,

$1731.25 \%$ at $37{ }^{\circ} \mathrm{C}$. This was performed to produce a more acid stressed population, as

174 described by Buchanan and Edelson (1996) with some modifications. The $\mathrm{pH}$ of the 175 culture following overnight incubation was measured using a $\mathrm{pH}$ meter with a glass

176 electrode and was found to be in the range of 4.4-4.6. Cultures were then centrifuged as 177 described above and cell pellet was resuspended directly in 10ml orange juice ( $\mathrm{pH} 3.5$ -

178 3.7) and incubated at $37^{\circ} \mathrm{C}$ for $90 \mathrm{~min}$. Cultures were further diluted in orange juice to 179 yield an approximate final concentration of $10^{6}-10^{7}$ cells $/ \mathrm{ml}$ and then ozone treatment 180 was applied.

$181 \quad 2.5$ Ozone treatment

182 Ozone gas was generated using an ozone generator (Model OL80, Ozone services, 183 Burton, Canada, Fig. 1). Ozone was produced by a corona discharge generator. Pure 184 oxygen was supplied via an oxygen cylinder (Air Products Ltd., Dublin, Ireland) and the 
185 flow rate was controlled using an oxygen flow regulator. A previously determined

186 optimum flow rate of $0.12 \mathrm{~L} / \mathrm{min}$ with an ozone concentration of $0.098 \mathrm{mg} / \mathrm{min} / \mathrm{ml}$ was

187 applied for each treatment (Patil, Cullen, Kelly, Frias \& Bourke, 2009b). Excess ozone

188 was destroyed by an ozone destroyer unit. To prevent excess foaming, $20 \mu \mathrm{l}$ sterile anti-

189 foaming agent (Antifoam B emulsion, Sigma Aldrich, Ireland Ltd.) was added before

190 each ozone treatment. The treatment of all orange juice samples previously inoculated

191 with Listeria strains (as described in section 2.4) was carried out for 7-8 minutes with

192 sampling intervals of $1 \mathrm{~min}$. All experiments were performed in duplicate and replicated

193 at least twice.

\section{$194 \quad 2.6$ Microbiological analysis}

195 The efficacy of treatment was determined in terms of reduction in viable counts over

196 time. Populations of challenge organism were determined by plating onto TSA and

197 selective media (Palcam), respectively. Samples (1ml aliquots) were withdrawn from

198 treated juice at specific time intervals, serially diluted in MRD and $0.1 \mathrm{ml}$ aliquots of

199 appropriate dilutions were surface plated on TSA and Palcam agar. Plates were incubated

200 at $37^{\circ} \mathrm{C}$ for $48 \mathrm{~h}$ and then colony forming units were counted. Results were reported as

$201 \log _{10} \mathrm{CFU} / \mathrm{ml}$. Data were pooled and average values and standard deviations were

202 determined. Means were compared using ANOVA followed by LSD testing at $\mathrm{p}<0.05$

203 level (SPSS, version 15.0).

\section{$204 \quad 2.7$ Microbial inactivation kinetics}

205 The GInaFiT tool was employed to perform the regression analysis of the microbial 206 inactivation data (Geeraerd, Valdramidis \& Van Impe, 2005). The Weibull model

207 (Mafart, Couvert, Gaillard \& Leguerinel, 2002) was used to analyze the data: 
$208 \quad \log _{10}(N)=\log _{10}\left(N_{0}\right)-\left(\frac{t}{\delta}\right)^{p}$

209 where $N(\mathrm{CFU} / \mathrm{ml})$ is the number of microorganisms at time t, $N_{0}(\mathrm{CFU} / \mathrm{ml})$ is the initial

210 number of microorganisms, $\delta[\mathrm{min}]$ (time for the first decimal reduction) and $p[-]$ are

211 parameters related to the scale and shape of the inactivation curve, respectively. The

212 Weibull distribution corresponds to a concave upward survival curve if $p<1$ and concave

213 downward if $p>1$ (van Boekel, 2002).

214 The numerical estimates of $\delta$ and $p$ were used to calculate a desired log reduction. The

215 time required to obtain a $5 \log$ reduction $\left(\mathrm{t}_{x d}\right)$ was calculated using equation 3 . For this

216 case study $x$ was equal to 5

$217 t_{x d}=\delta \times(x)^{\frac{1}{p}}$

$218 \quad 2.8$ Determination of degree of injury and recovery index

219 The non-selective medium TSA was expected to support the growth of both uninjured

220 and ozone injured cells whereas the selective medium, Palcam agar was expected to

221 support growth of uninjured populations. The difference from selective to non-selective

222 media gives an indication of cell injury during the ozone treatment. Percent injury was

223 calculated by using equation 3 (Hansen \& Knochel, 2001). It was calculated by choosing

224 the time intervals of samples which resulted in colony formation on both the media used.

225

226

227

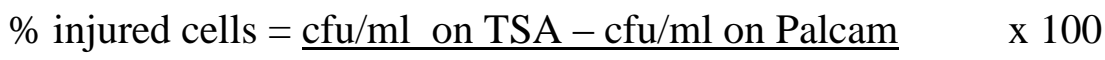

228

cfu/ml on TSA 
229 A recovery index was defined as the $\mathrm{t}_{5 d}$ (time required to obtain a $5 \log$ reduction)

230 determined from the counts on the Palcam divided by $\mathrm{t}_{5 d}$ determined from the counts on

231 TSA (Hansen \& Knochel, 2001).

\section{3. Results}

233 The inactivation kinetics of Listeria in orange juice were fitted using the Weibull model,

234 which provided estimations of microbial inactivation parameters in terms of the

235 processing times required. The Weibull parameters $\delta$ and $p$ are shown in Table 1. The

236 shape parameter $p$, gave downward concavity for the kinetic curves of all the Listeria

237 strains (Figs. 2, 3 and 4). $p$ values of $>1$ indicates a greater susceptibility of

238 microorganisms to the treatment (van Boekel, 2002).

$239 \quad 3.1$ Inactivation of Listeria monocytogenes NCTC 11994

240 The inactivation curves of L. monocytogenes NCTC 11994 are shown in Fig. 2. Ozone

241 treatment of mild acid stressed population required a longer treatment time to achieve

242 reduction by $5 \log$ cycles $\left(\mathrm{t}_{5 d}\right)$ compared to control non acid-stressed cells. For these test

243 conditions, significant differences were observed for recovery index as well as for $\mathrm{t}_{5 d}$

$244(\mathrm{p}<0.05)($ Table 1). Ozone treatment of $18 \mathrm{~h}$ acid stress-habituated population recorded

245 the highest time required for achieving $\mathrm{t}_{5 d}$ compared to other test conditions investigated

246 (Table 1). Recovery index and $\mathrm{t}_{5 d}$ values for acid stress-habituated cells showed

247 significant difference compared to the other test conditions $(\mathrm{p}<0.05)$. In the case of acid 248 stressed cells habituated in orange juice, $\mathrm{t}_{5 d}$ was achieved in comparatively less time than 249 that required for mild acid stressed and $1 \mathrm{~h}$ or $18 \mathrm{~h}$ acid stress-habituated cells (Table 1).

250 In the case of cells habituated in orange juice, lower \% injury was obtained (Table 1) and

251 for the precise estimation of the uninjured vs. the injured population, counts on Palcam 
252 agar were recorded for up to 6 min of ozone treatment by which time the detection limit

253 was not reached for both media used.

\section{$254 \quad 3.2$ Inactivation of Listeria monocytogenes ATCC 7644}

255 Survivor curves for Listeria strain ATCC 7644 following ozone treatments are presented

256 in Fig. 3. In the case of control non acid-stressed, mild acid stressed and acid stressed

257 cells habituated in orange juice, $\mathrm{t}_{5 d}$ was achieved in less than 6 min of ozone treatment

258 with no significant differences obtained with the recovery index for any of the test

259 conditions studied (Table 1).

260 In the case of acid stress-habituated populations ( $1 \mathrm{~h}$ and $18 \mathrm{~h}$ ), a significant difference

261 was observed in $t_{5 d}$ values compared to the three other test conditions investigated

262 (p<0.05). At all test conditions where acid stress was applied, $\geq 97.4 \%$ injury was

263 observed indicating the efficacy of ozone in conjunction with applied acid stress

264 conditions (Table 1). However, for the control non acid stressed cells, a smaller \% injury

265 was observed.

\section{$266 \quad 3.3$ Inactivation of Listeria innocua NCTC 11288}

267 Ozone inactivation curves of L. innocua cells for different test conditions are shown in

268 Fig. 4. The control non acid-stressed and mild acid stressed cells were reduced by $5 \log$

269 cycles in short treatment times (Table 1).

270 Mild acid stress-habituation of cells for the longer duration (18h) followed by

271 ozone treatment resulted in significantly higher $t_{5 d}$ value compared to other test

272 conditions investigated (Table 1). However, a significant difference was observed in $\mathrm{t}_{5 d}$

273 values for orange juice habituated cells, compared with mild acid stressed cells and

274 control non acid-stressed cells $(\mathrm{p}<0.05)$. 
275 The lower \% injury observed for acid stressed cells habituated in orange juice after $7 \mathrm{~min}$

276 ozone treatment underlines the importance of investigating the efficacy of ozone in real

277 product formulations in addition to simulated stress conditions in model media.

278 4. Discussion

279 The direct application of ozone was found to be effective for the inactivation of Listeria

280 in orange juice (Figs. 2, 3, and 4). However, there were some significant effects of

281 bacterial cell pre-treatment and condition observed on inactivation efficacy. The pre-

282 treatments and conditions employed were designed to mimic the environment that a

283 contaminating population could be exposed to in orange juice and other food processing

284 scenarios. Literature studies on the efficiency of ozone for inactivating Listeria in food

285 products vary (Olmez \& Akbas, 2009; Rodgers, Cash, Siddiq \& Ryser, 2004; Vaz-Velho,

286 Silva, Pissoa \& Gibbs, 2006; Yuk, Yoo, Yoon, Moon, Marshall \& Oh, 2006). Olmez \&

287 Akbas (2009), stated that the efficiency of ozone treatment can be related to the delivery

288 method.

289 Applying a mild acid stress actually increased the ozone treatment time required

290 for a $5 \log$ reduction for both strains of L. monocytogenes by comparison with the control

291 population. However, in the case of L. innocua, applying a mild acid stress did not

292 significantly effect the ozone treatment time required by comparison with the control.

293 Leistner (2000) reported that simultaneous exposure of bacteria to different stress factors

294 requires increased energy consumption and leads bacteria to cellular death through

295 metabolic exhaustion.

296 Foodborne bacteria encounter organic and inorganic acids in foods or in the

297 gastrointestinal tract and cells of the host (Yousef \& Courtney, 2003). Adaptation of $L$. 
monocytogenes to sublethal stresses has been demonstrated to protect the pathogen to a

299 variety of normally lethal conditions present in certain foods (Lou and Yousef, 1997).

300 The resistance or adaptation of microorganisms to acid conditions can have implications

301 for food safety. In this study, acid stress-habituated Listeria cells had an increased

302 resistance to ozone treatment and also recorded the highest time for achieving $5 \log \left(\mathrm{t}_{5 d}\right)$

303 reductions. Similar findings of significantly increased resistance of L. monocytogenes to

304 heat were reported by Mazzotta (2001) after acid adaptation of Listeria in single strength

305 apple, orange and white grape juices adjusted to $\mathrm{pH}$ 3.9. Caggia et al. (2009) recorded the

306 highest acid tolerance response of L. monocytogenes OML 45 strain, after $3 \mathrm{~h}$ treatment in

307 TSB adjusted to $\mathrm{pH}$ 5.7, thus concluding that cells adapted to acidic environments can

308 grow in normally lethal $\mathrm{pH}$ conditions.

309 It has been reported that the heat and acid resistance of L. monocytogenes are strain

310 dependant (Skandamis, Yoon, Stopforth, Kendall \& Sofos, 2008). Phan-Thanh et al.

311 (2000) reported the lowest $\mathrm{pH}$ value which $L$. monocytogenes could resist was dependant

312 on the strain and the kind of acid used. Our results also showed that the extent of

313 increased acid resistance varied with the bacterial strain and acid stress conditions. Strain

314 NCTC 11994 was the most resistant strain independent of the applied conditions.

315 In orange juice production, low acidic conditions are present before the pasteurization

316 process and may induce an ATR that can result in increased thermal tolerance (Caggia et

317 al., 2009). The exposure to sequential acid stressors such as a prior acid stress followed

318 by an acid environment in the product may result in cross protection to a subsequent

319 processing treatment as observed here. In the case of all $18 \mathrm{~h}$ acid stress-habituated

320 populations, the highest $t_{5 d}$ values were estimated, however, lower recovery indices were 
321 reported, where greater recovery of cells was evident on non-selective media by

322 comparison with selective media (Table 1). The applied acid stress did not promote

323 recovery on selective medium (Palcam) at the same rate of the recovery on non-selective

324 medium (TSA), however the injured sub-population may have a greater resistance to

325 ozone. Therefore, to mimic the stresses encountered in food processing environments,

326 conditions like acid stress-habituation and habituation in actual orange juice should be

327 considered for determining inactivation parameters (e.g., $t_{x d}$, \%injury, recovery index)

328 and process design in foods.

329 From the present study and based on the different inactivation responses to ozone

330 treatment it was also observed that inactivation responses of L. innocua NCTC 11288

331 were closer to those of L. monocytogenes ATCC 7644 than L. monocytogenes NCTC 33211994.

\section{5. Conclusions}

334 This work has shown that direct ozone treatment can be used to inactivate $L$. 335 monocytogenes and L. innocua in orange juice. The efficacy of ozone treatment was

336 found to be a function of strain and duration of acid stress-habituation conditions. The

337 data also indicate that adaptive stress responses should be taken into account for process

338 design or method development for the inactivation of $L$. monocytogenes. Inactivation

339 times for a $5 \log$ cycle reduction were achieved in between 5.08 and $8.44 \mathrm{~min}$. Therefore,

340 direct ozone diffusion treatment could be used as a potential alternative to traditional

341 thermal pasteurisation for control of Listeria populations in fruit juices or other liquid 342 foods.

\section{Acknowledgement}


344 Funding for this research was provided under the National Development Plan 2000-2006,

345 through the Food Institutional Research Measure, administered by the Department of

346 Agriculture, Fisheries \& Food, Ireland.

\section{References}

348 Buchanan, R. L., \& Edelson, S. G. (1996). Culturing enterohemorrhagic Escherichia coli

349 in the presence and absence of glucose as a simple means of evaluating the acid tolerance

350 of stationary-phase cells. Applied and Environment Microbiology, 62, 4009-4013.

351 Burleson, G. R., Murray, T., M., \& Pollard, M. (1975). Inactivation of viruses and

352 bacteria by ozone with and without sonication. Applied Microbiology, 29, 340-344.

353 Caggia, C., Ombretta Scifò, G., Restuccia, C., \& Randazzo, C. L. (2009) Growth of acid-

354 adapted Listeria monocytogenes in orange juice and in minimally processed orange 355 slices. Food Control, 20(1), 59-66.

356 Cheng, H.Y., Yu, R., C., \& Chou, C.C. (2003). Increased acid tolerance of Escherichia 357 coli $\mathrm{O} 157: \mathrm{H} 7$ as affected by acid adaptation time and conditions of acid challenge. Food 358 Research International, 36, 49-56.

359 Cotter, P.D., Gahan, C.G.M., \& Hill, C. (2000). Analysis of the role of the Listeria 360 monocytogenes F0F1-ATPase operon in the acid tolerance response. International 361 Journal of Food Microbiology, 60, 137-146.

362 Esteve M.J., \& Frígola A. (2007). Refrigerated fruit juices: quality and safety issues. 363 Advances in Food Nutrition Research, 52,103-139.

364 Fan, L., Song, J., McRae, K. B., Walker, B. A., \& Sharpe, D. (2007) Gaseous ozone 365 treatment inactivates Listeria innocua in vitro. Journal of Applied Microbiology, 103(6), $366 \quad 2657-2663$. 
367 Foster, J. W. (1991). Salmonella acid shock proteins are required for the adaptive acid

368 tolerance response. Journal of Bacteriology, 173, 6896-6902.

369 Geeraerd, A.H., Valdramidis, V. P., \& Van Impe, J.F. (2005). GInaFit, a freeware tool to

370 assess non-log-linear microbial survivor curves. International Journal of Food

371 Microbiology, 102, 95-105.

372 Hansen, T. B., \& Knochel, S. (2001). Factors influencing resuscitation and growth of heat

373 injured Listeria monocytogenes 13-249 in sous vide cooked beef. International Journal of

374 Food Microbiology, 63(1-2), 135-147.

375 Johnson, E. A. (2003). Microbial adaptation and survival in foods. In: Microbial Stress

376 adaptation and Food Safety (pp 84-85). Ed: Yousef and Juneja, CRC press.

377 Kim, J.G., Yousef, A.E., \& Dave, S. (1999). Application of ozone for enhancing the

378 microbiological safety and quality of foods: A review. Journal of Food Protection, 62(9),

$379 \quad 1071-1087$.

380 Koutsoumanis, K.P., \& Sofos, J.N. (2004). Comparative acid stress response of Listeria

381 monocytogenes, Escherichia coli O157:H7 and Salmonella typhimurium after

382 habituation at different pH conditions. Letters in Applied Microbiology, 38, 321-326.

383 Leistner, L. (2000) Basic aspects of food preservation by hurdle technology.

384 International Journal of Food Microbiology, 55, 181- 186.

385 Lou, Y., \& Yousef, A. E. (1997). Adaptation to sublethal environmental stresses protect

386 Listeria monocytogenes against lethal preservation factors. Applied and Environmental

387 Microbiology, 63, 1252-1255. 
388 Mafart, P., Couvert, O., Gaillard, S., \& Leguerinel, I. (2002). On calculating sterility in

389 thermal preservation methods: application of Weibull frequency distribution model.

390 International Journal of Food Microbiolology, 72, 107-113.

391 Mazzotta, A. S. (2001). Thermal inactivation of stationary-phase and acid-adapted

392 Escherichia coli O157:H7, Salmonella, and Listeria monocytogenes in fruit juices.

393 Journal of Food Protection, 64, 315-320.

394 Muthukumarappan, K., Halaweish, F., \& Naidu, A.S. (2000). Ozone. In: Natural Food

395 Anti-Microbial Systems (pp. 783-800). A.S. Naidu, Eds. CRC Press, Boca Raton, FL.

396 Ölmez, H., \& Akbas, M. Y. (2009). Optimization of ozone treatment of fresh-cut green

397 leaf lettuce. Journal of Food Engineering, 90 (4), 487-494.

398 Oyarzábal, O. A., Nogueira M. C. L., \& Gombas, D. E. (2003). Survival of Escherichia 399 coli O157:H7, Listeria monocytogenes, and Salmonella in Juice Concentrates. Journal of $400 \quad$ Food Protection, 66(9), 1595-1598.

401 Patil, S., Bourke, P., Frias, J. M., Tiwari, B. K., \& Cullen, P. J. (2009a). Inactivation of 402 Escherichia coli in orange juice using ozone. Innovative Food Science and Emerging 403 Technologies, 10, 551-557.

404 Patil, S., Cullen, P. J., Kelly, B., Frias, J. M. and Bourke, P., (2009b). Extrinsic control 405 parameters for ozone inactivation of Escherichia coli using ozone bubble column. 406 Journal of Applied Microbiology, 107(3), 830-837.

407 Phan-Thanh, L., Mahouin, F., \& Alige, S. (2000). Acid responses of Listeria 408 monocytogenes. International Journal of Food Microbiology, 55(1-3), 121-126. 
409 Picart, L. T., Dumay, E., \& Cheftel, J. C. (2002). Inactivation of Listeria innocua in dairy

410 fluids by pulsed electric fields: influence of electric parameters and food composition.

411 Innovative Food Science and Emerging Technologies, 3, 357-369.

412 Rodgers, S. L., Cash, J. N., Siddıq, M., \& Ryser, E.T. (2004). A comparison of different

413 chemical sanitizers for inactivating Escherichia coli O157:H7 and Listeria

414 monocytogenes in solution and on apples, lettuce, strawberries \& cantaloupe. Journal of

415 Food Protection, 67, 721-731.

416 Ryser, E. T., \& Marth, E. H. (ed.) 1991. Listeria, listeriosis, and food safety. Marcel

417 Dekker, New York.

418 Sado, P. N., Jinneman, K. C., Husby, G. J., Sorg, S. M., \& Omiecinsky, C. J. (1998).

419 Identification of Listeria monocytogenes from pasteurized apple juice using rapid test 420 kits. Journal of food protection, 61, 1199-1202.

421 Skandamis, P. N., Yoon, Y., Stopforth, J, D., Kendall, P, A., \& Sofos, J, N. (2008). Heat

422 and acid tolerance of Listeria monocytogenes after stress to single and multiple sublethal

423 stresses. Food Microbiology, 25, 294-303.

424 Tiwari, B. K., Muthukumarappan, K., O’Donnell, C. P., \& Cullen, P. J. (2008). Kinetics 425 of freshly squeezed orange juice quality changes during ozone processing. Journal of 426 Agricultural Food Chemistry, 56, 6416-6422.

427 Tiwari, B. K., Muthukumarappan, K., O’Donnell, C. P., \& Cullen, P. J. (2009a). 428 Anthocyanin and colour degradation in ozone treated blackberry juice. Innovative Food 429 Science and Emerging Technologies, 10, 70-75. 
430 Tiwari, B. K., O’Donnell, C. P., Patras, A., Brunton, N., \& Cullen, P. J. (2009b). Effect of

431 ozone processing on anthocyanins and ascorbic acid degradation of strawberry juice.

432 Food Chemistry, 113, 1119-1126.

433 United States Food and Drug Administration, USFDA (2004a). Juice HACCP Hazards

434 and Controls Guidance. Guidance for industry (First edition). Available at:

435 http://www.cfsan.fda.gov/ dms/juicgu10.html

436 USFDA (2004b). FDA Guidance to Industry, 2004: Recommendations to Processors of

437 Apple Juice or Cider on the Use of Ozone for Pathogen Reduction Purposes.

438 Available online <http://www.cfsan.fda.gov/ dms/juicgu13.html>.

439 van Boekel, M. A. J. S. (2002). On the use of the Weibull model to describe thermal

440 inactivation of microbial vegetative cells. International Journal of Food Microbiology,

$44174(1-2), 139-159$.

442 Vaz-Velho, M., Silva, M., Pessoa, J., \& Gibbs, P.(2006). Inactivation by ozone of

443 Listeria innocua on salmon-trout during cold-smoke processing. Food Control,

444 17(8), 609-616.

445 Yousef, A. E., \& Courtney, P. (2003). Basics of stress adaptation and implications in 446 new-generation foods. In Yousef and Juneja, Microbial Stress adaptation and Food 447 Safety. (pp-1-30). CRC press

448 Yuk, H. G., Yoo, M. Y., Yoon, J. W., Moon, K. D., Marshall, D. L., \& Oh, D. H. (2006).

449 Effect of combined ozone and organic acid treatment for control of Escherichia coli

450 O157:H7 and Listeria monocytogenes on lettuce. Journal of Food Science, 71, 83-87. 


\section{$453 \quad$ Figure captions}

454 Figure $1 \quad$ Schematics of the ozone processing equipment.

455 Figure 2 Ozone inactivation of Listeria monocytogenes NCTC 11994

456 (a) Control non acid-stressed cells

(b) Mild acid-stressed cells

(c) $1 \mathrm{~h}$ acid stress-habituated cells

(d) $18 \mathrm{~h}$ acid stress-habituated cells

(e) Habituated cells in orange juice

Figure 3 Ozone inactivation of Listeria monocytogenes ATCC 7644

(a) Control non acid-stressed cells

(b) Mild acid-stressed cells

(c) $1 \mathrm{~h}$ acid stress-habituated cells

(d) $18 \mathrm{~h}$ acid stress-habituated cells

(e) Habituated cells in orange juice

467 Figure $4 \quad$ Ozone inactivation of Listeria innocua NCTC 11288

(a) Control non acid-stressed cells

(b) Mild acid-stressed cells

(c) $1 \mathrm{~h}$ acid stress-habituated cells

(d) $18 \mathrm{~h}$ acid stress-habituated cells

(e) Habituated cells in orange juice 
Table 1: Parameters of the Weibull model and the time required to reach a 5 log reduction for Listeria strains in orange juice (Different letters indicate a significant difference at the 0.05 level between each type of condition).

\begin{tabular}{|c|c|c|c|c|c|c|c|}
\hline Microorganism & Condition & $\delta(\min ) \pm \mathrm{STE}$ & $\mathrm{p} \pm \mathrm{STE}$ & $\mathrm{R}^{2}$ & $t_{5 d}(\min )$ & $\begin{array}{l}\text { Recovery } \\
\text { index }\end{array}$ & $\%$ injury \\
\hline \multirow{5}{*}{$\begin{array}{l}\text { L. monocytogenes } \\
\text { NCTC } 11994\end{array}$} & Control non-acid stressed & $3.48 \pm 0.64$ & $3.17 \pm 1.04$ & 0.93 & $5.78^{\mathrm{a}}$ & $0.99^{k}$ & 95.9 \\
\hline & mild-acid stressed cells & $3.07 \pm 0.55$ & $1.97 \pm 0.41$ & 0.96 & $6.95^{\mathrm{b}}$ & $0.76^{1}$ & 99.7 \\
\hline & 1h acid stress-habituation & $4.05 \pm 0.40$ & $2.64 \pm 0.38$ & 0.98 & $7.45^{\mathrm{c}}$ & $0.79^{1}$ & 97.8 \\
\hline & $18 \mathrm{~h}$ acid stress-habituation & $4.45 \pm 0.69$ & $2.52 \pm 0.65$ & 0.93 & $8.44^{\mathrm{d}}$ & $0.60^{\mathrm{lm}}$ & 99.9 \\
\hline & Habituated cells in orange juice & $2.96 \pm 0.73$ & $1.97 \pm 0.48$ & 0.94 & $6.69^{\mathrm{ab}}$ & $0.89^{\mathrm{k}}$ & 76.6 \\
\hline \multirow{5}{*}{$\begin{array}{l}\text { L. monocytogenes } \\
\text { ATCC } 7644\end{array}$} & Control non-acid stressed & $2.99 \pm 0.47$ & $2.84 \pm 0.64$ & 0.94 & $5.27^{\mathrm{e}}$ & $0.98^{\mathrm{n}}$ & 91.6 \\
\hline & mild-acid stressed cells & $3.17 \pm 0.30$ & $2.89 \pm 0.42$ & 0.98 & $5.53^{\mathrm{e}}$ & $1.00^{\mathrm{n}}$ & 99.8 \\
\hline & 1h acid stress-habituation & $4.12 \pm 0.90$ & $2.74 \pm 0.89$ & 0.90 & $7.41^{\mathrm{f}}$ & $0.75^{\circ}$ & 99.3 \\
\hline & $18 \mathrm{~h}$ acid stress-habituation & $4.54 \pm 0.52$ & $3.00 \pm 0.60$ & 0.95 & $7.77^{\mathrm{f}}$ & $0.80^{\mathrm{n}}$ & 99.2 \\
\hline & Habituated cells in orange juice & $1.43 \pm 0.56$ & $1.14 \pm 0.24$ & 0.95 & $5.87^{\mathrm{e}}$ & $0.86^{\mathrm{n}}$ & 97.4 \\
\hline \multirow{5}{*}{$\begin{array}{l}\text { L. innocua NCTC } \\
11288\end{array}$} & Control non-acid stressed & $2.94 \pm 0.66$ & $2.66 \pm 0.82$ & 0.91 & $5.38^{\mathrm{h}}$ & $0.96^{\mathrm{p}}$ & 74.6 \\
\hline & mild-acid stressed cells & $3.44 \pm 0.47$ & $4.14 \pm 1.45$ & 0.94 & $5.08^{h}$ & $1.0^{\mathrm{q}}$ & 99.8 \\
\hline & 1h acid stress-habituation & $4.17 \pm 0.34$ & $4.33 \pm 0.96$ & 0.97 & $6.05^{\mathrm{i}}$ & $0.85^{\mathrm{pr}}$ & 98.4 \\
\hline & $18 \mathrm{~h}$ acid stress-habituation & $4.12 \pm 0.42$ & $2.62 \pm 0.40$ & 0.97 & $7.60^{j}$ & $0.80^{\mathrm{r}}$ & 89.5 \\
\hline & Habituated cells in orange juice & $1.82 \pm 0.88$ & $1.30 \pm 0.40$ & 0.91 & $6.26^{\mathrm{i}}$ & $0.83^{\mathrm{r}}$ & 66.7 \\
\hline \\
\hline \multicolumn{8}{|c|}{$\begin{array}{ll}\delta- & \text { time for the first decimal reduction } \\
\text { STE }- & \text { standard error }\end{array}$} \\
\hline \multirow{3}{*}{\multicolumn{8}{|c|}{$\begin{array}{ll}p- & \text { parameters related to the scale and shape of the inactivation curve } \\
\mathrm{R}^{2}- & \text { coefficient of determination }\end{array}$}} \\
\hline & & & & & & & \\
\hline \multicolumn{2}{|c|}{$\%$ injury- $\quad$ calculated using equation 1} & & & & & & \\
\hline \multicolumn{8}{|c|}{ Recovery index- $\mathrm{t}_{5 d}$ determined on Palcam divided by $\mathrm{t}_{5 d}$ determined on TSA } \\
\hline
\end{tabular}




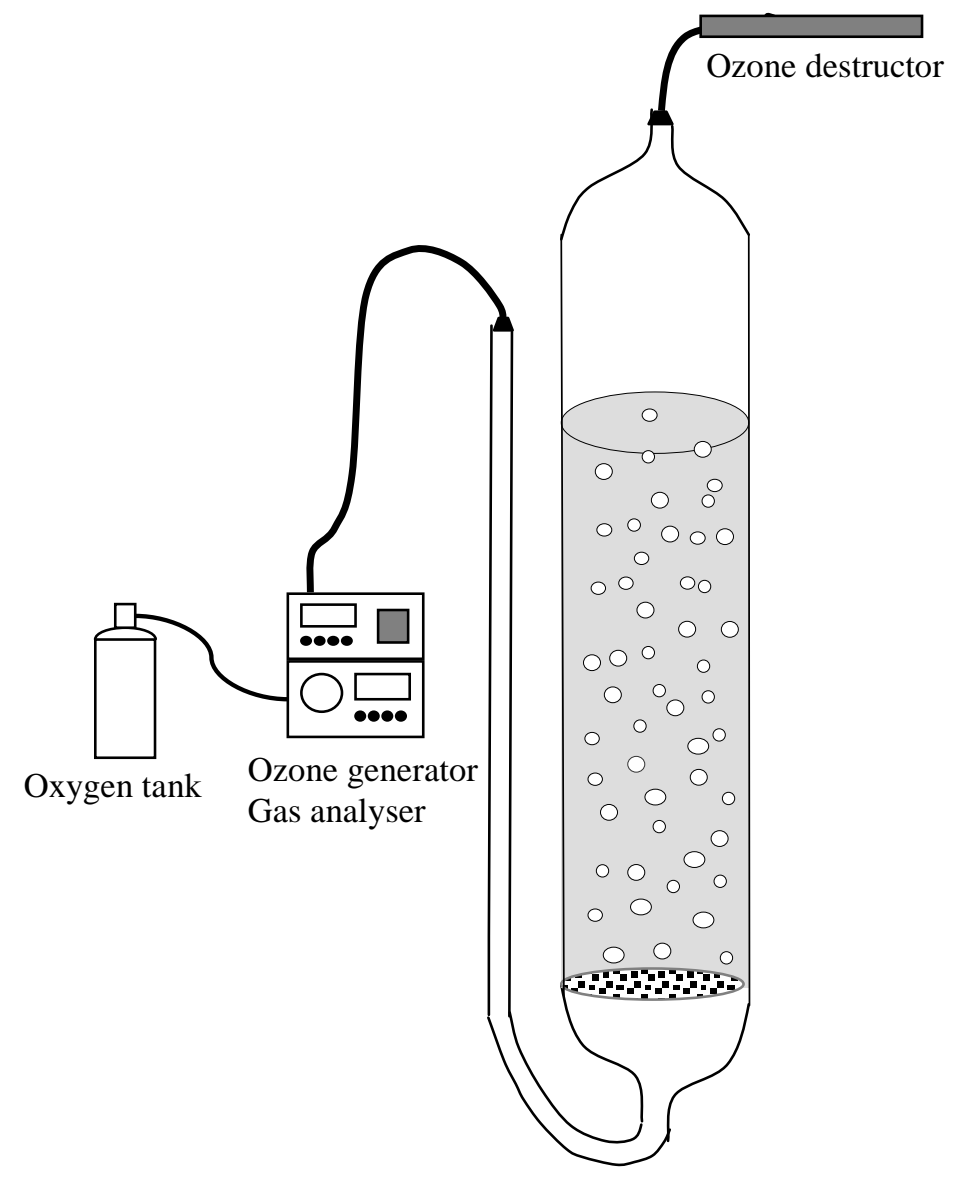

Fig. 1 
(a)
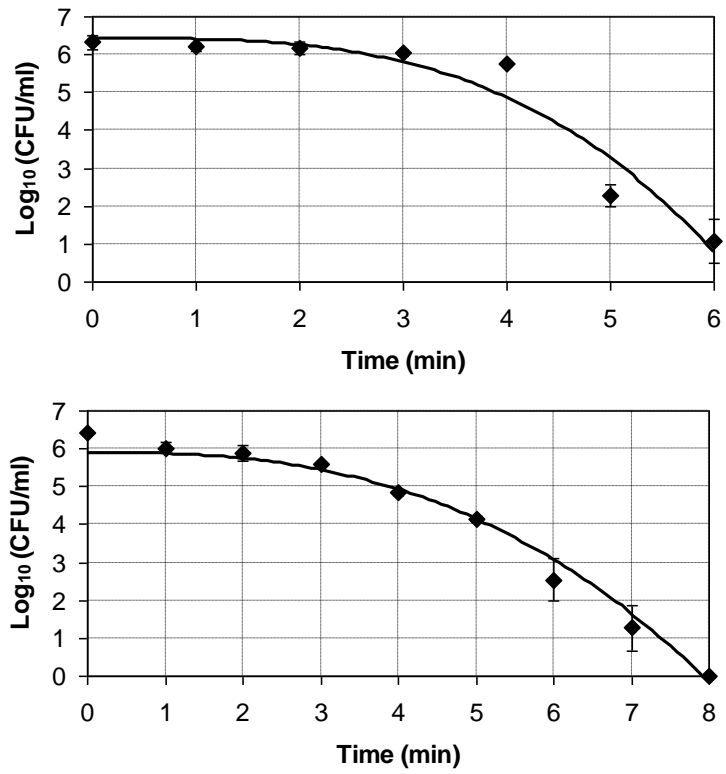

(c) (b)
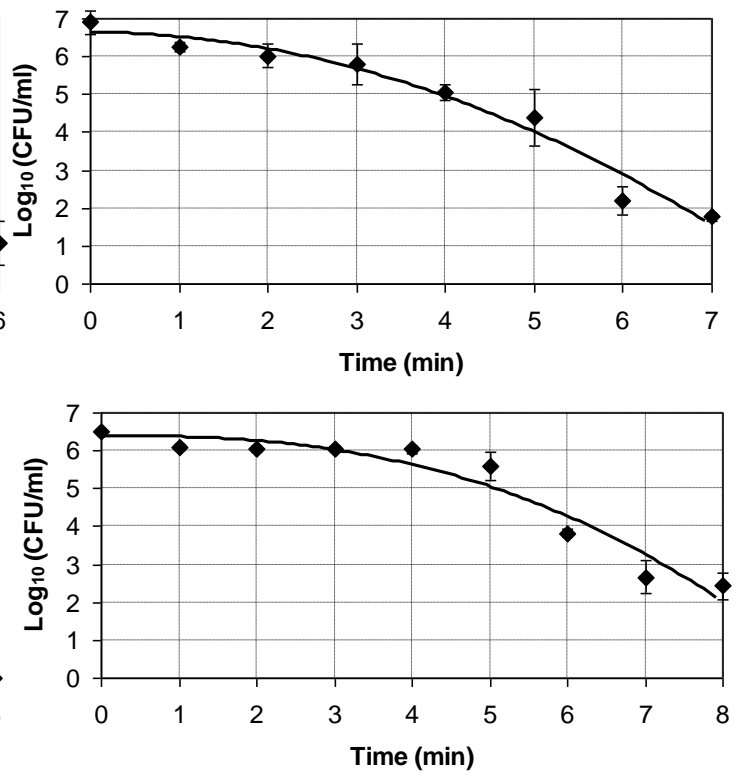

(d)

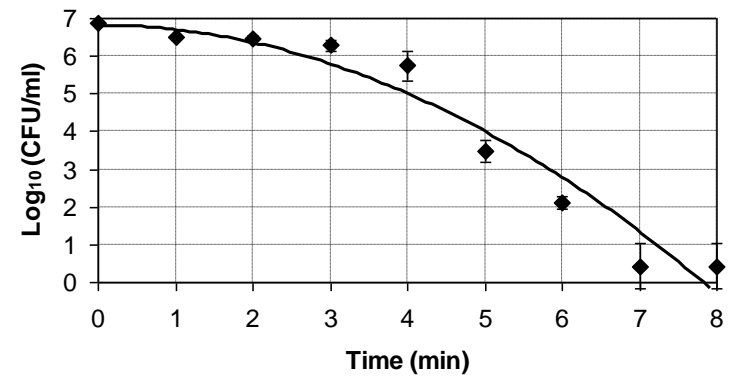

(e)

Fig. 2 
(a)
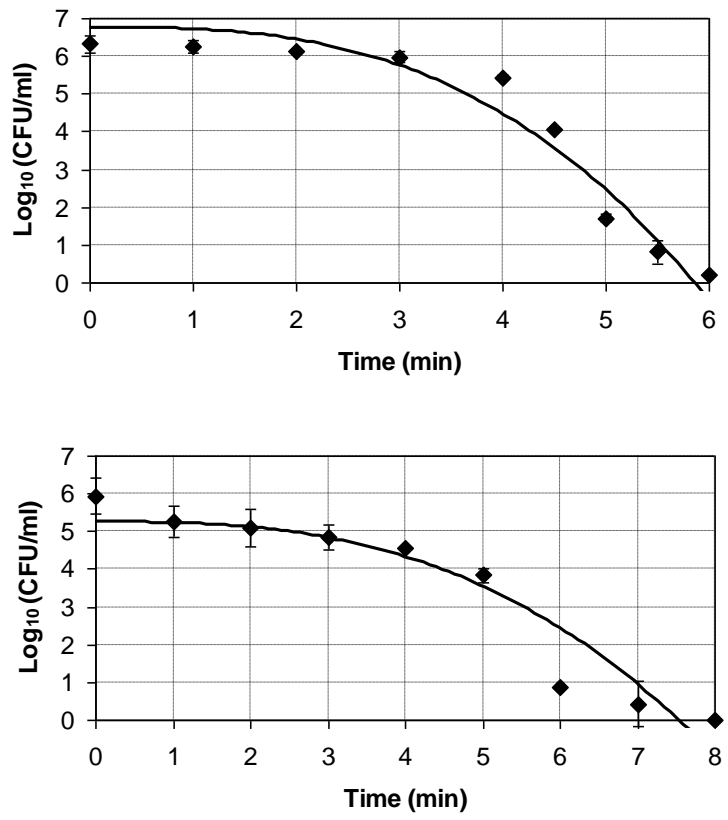

(c) (b)
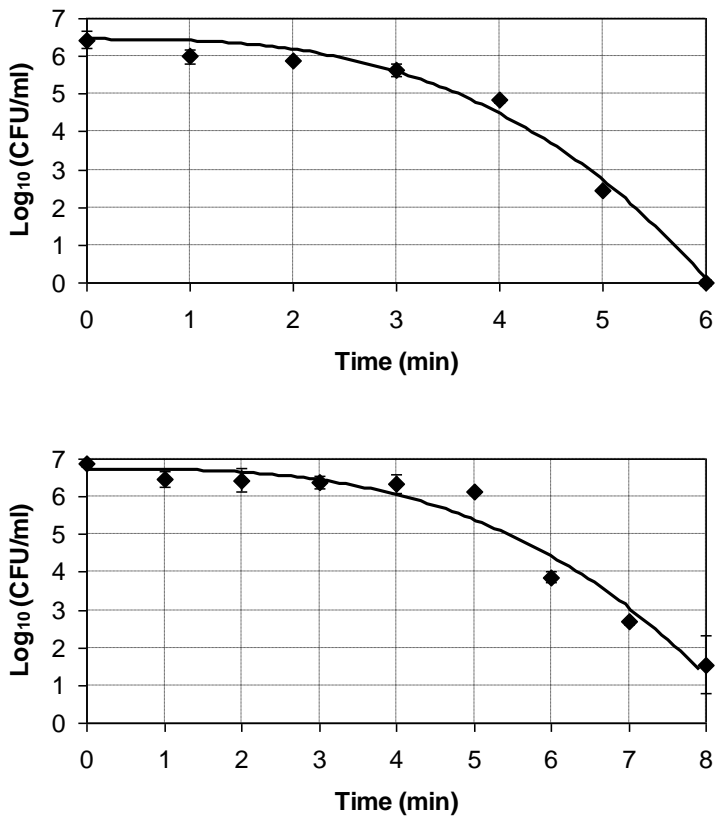

(d)

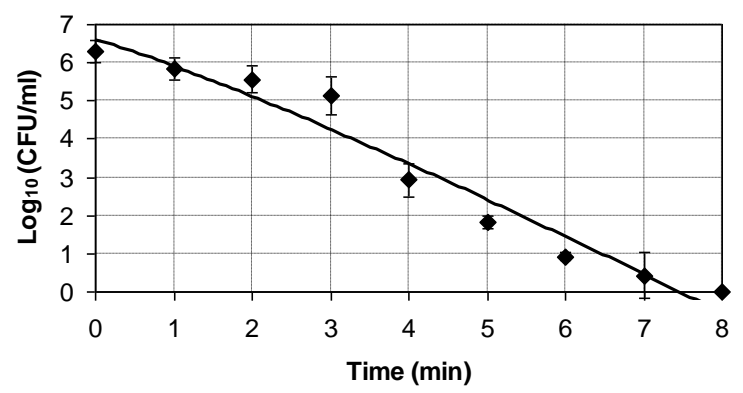

(e)

Fig. 3 
(a)
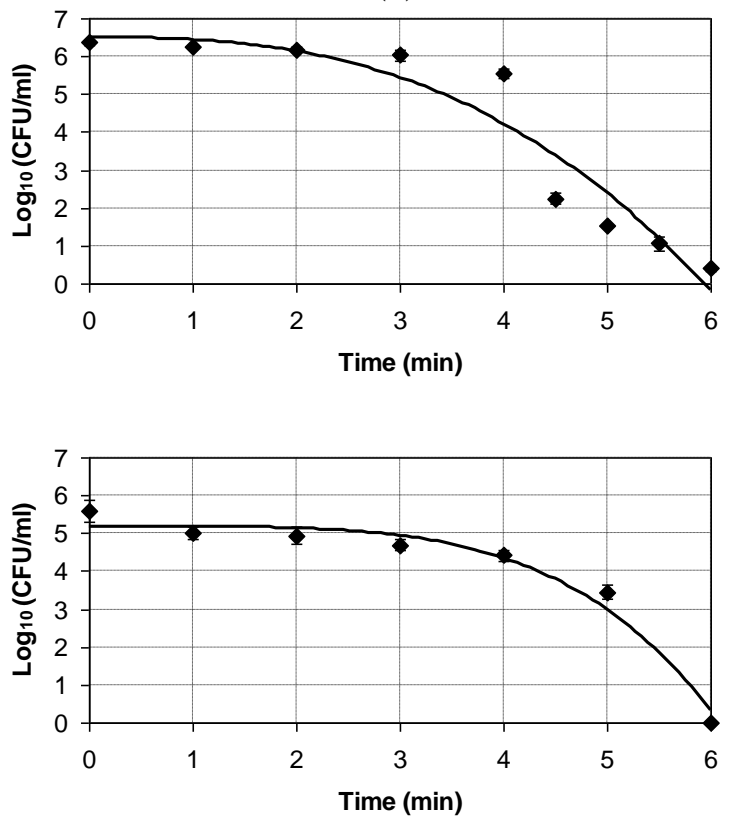

(c) (b)
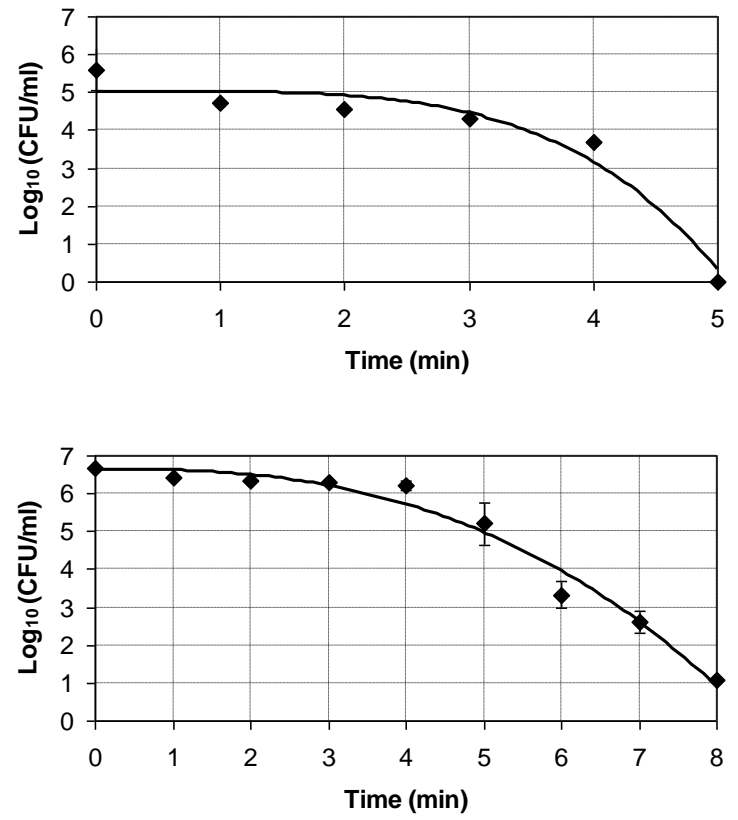

(d)

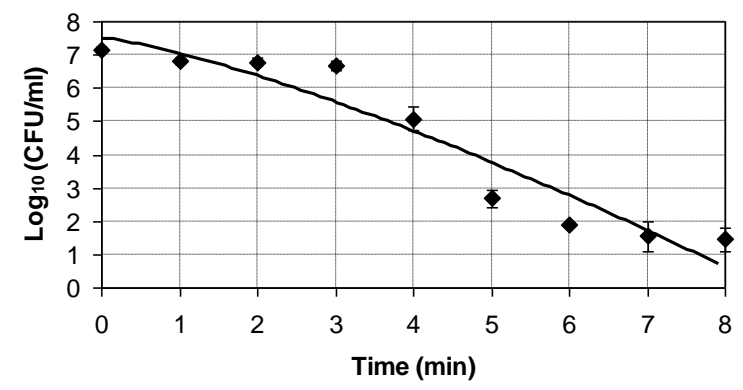

(e)

Fig. 4 